\title{
Simulasi Numerik Karakteristik Pembakaran Pada Tangentially Fired Boiler Dengan Variasi Sudut Yaw
}

\author{
Rindra Hosanova ${ }^{1}$, Devy Setiorini Sa'adiyah ${ }^{2}$, Diniar Mungil Kurniawati ${ }^{3}$ \\ ${ }^{1}$ Program Studi Teknik Mesin, Jurusan Teknologi Industri dan Proses, Institut Teknologi Kalimantan, \\ Balikpapan. Email: rindrahosanova@gmail.com \\ ${ }^{2}$ Program Studi Teknik Mesin, Jurusan Teknologi Industri dan Proses, Institut Teknologi Kalimantan, \\ Balikpapan. Email: devysetiorini@lecturer.itk.ac.id \\ ${ }^{3}$ Program Studi Teknik Mesin, Jurusan Teknologi Industri dan Proses, Institut Teknologi Kalimantan, \\ Balikpapan. Email: diniarmungil@lecturer.itk.ac.id
}

\begin{abstract}
Coal is one of the energy sources that widely used for electricity, the age of coal reserves only remain 56 years, so it is necessary to make a study to reduce the consumption rate of coal with make an improvement on boiler efficiency which use tangentially fired boiler because it has good combustion. There is a problem in this type of boiler such as unbalance temperature and temperature deviation in superheaters and reheaters of the boiler. This research made to study the effect of yaw angle modification to temperature in boiler. Methode that used in this research is Computational Fluid Dynamic (CFD). Coal yaw angle modification in this research are $+5^{\circ}, 0^{\circ},-5^{\circ},-$ $10^{\circ}$, dan $-15^{\circ}$. Coal yaw angle modification have an effect to temperature distribution, the wider yaw angle the larger the temperature deviation. The best coal yaw angle configuration is at $-5^{\circ}$ because has the least temperature deviation on the upper furnace which minimize the risk of overheat on superheaters and reheaters.
\end{abstract}

Keywords: CFD, yaw angle, tangentially fired boiler

\begin{abstract}
Abstrak
Batubara merupakan salah satu sumber energi yang paling banyak dimanfaatkan sebagai pembangkit listrik. dengan umur cadangan batubara tersisa 56 tahun, maka perlu dilakukan penelitian untuk mengurangi tingkat konsumsi batubara yaitu dengan cara meningkatkan efisiensi dari boiler dengan menggunakan tangentially fired boiler karena mempunyai pembakaran yang baik. namun masih terdapat beberapa masalah seperti terdapat panas yang tidak seimbang dan terdapat deviasi temperatur pada super-heater dan reheater. Penelitian simulasi numerik karakteristik pembakaran dan emisi gas buang pada tangentially fired boiler dengan variasi sudut yaw bertujuan untuk mengetahui deviasi distribusi temperatur aliran yang terjadi pada berbagai sudut yaw burner. Penelitian dilakukan menggunakan metode Computational Fluid Dynamis (CFD). Variasi yang digunakan adalah variasi sudut yaw coal burner $+5^{\circ}, 0^{\circ},-5^{\circ},-10^{\circ}$, dan $-15^{\circ}$. Dengan merubah sudut yaw coal burner dapat berpengaruh terhadap distribusi temperatur yang terjadi pada boiler, semakin lebar sudut yaw coal burner maka semakin besar pula deviasi temperatur yang terjadi. Sudut yaw coal burner terbaik diperoleh pada pada sudut $-5^{\circ}$ dikarenakan mempunyai deviasi temperatur yang paling kecil dan rata, serta memiliki distribusi kecepatan yang baik sehingga menghasilkan bola api yang baik pada bagian furnace serta mempunyai temperatur terkecil pada upper furnace, sehingga memiliki resiko paling kecil terhadap terjadinya overheat pada heat exchanger.
\end{abstract}

Kata Kunci: CFD, sudut yaw, tangentially fired boiler

\section{Pendahuluan}

Batubara merupakan salah satu sumber energi yang paling banyak dimanfaatkan sebagai pembangkit listrik, menurut data yang diperoleh dari PT Bukit Asam sedikitnya 27 persen dari total energi yang dihasilkan didunia dan lebih dari 39 persen dari seluruh listrik yang dihasilkan didunia dihasilkan oleh pembangkit listrik bertenaga batubara, hal ini dikarenakan batubara memiliki proses ekstrasi yang relatif mudah dan murah, dan persyaratan infrastruktur yang lebih murah dibandingkan dengan sumber daya energi lainnya (BUMN, 2017). Berdasarkan data terakhir yang diperoleh dari Badan Geologi Kementerian Energi dan Sumber Daya Mineral (ESDM), cadangan batubara Indonesia sebesar 26.2 


\section{Simulasi Numerik Karakteristik Pembakaran Pada Tangentially Fired Boiler Dengan Variasi Sudut Yaw}

miliar ton. Dengan produksi batubara sebesar 461 juta pada tahun 2017, maka umur cadangan batubara tersisa 56 tahun apabila diasumsikan tidak ada temuan cadangan baru (KESDM 2016).

Untuk mengurangi tingkat konsumsi batubara maka perlu dilakukan penelitian dan inovasi yang lebih lanjut. Telah banyak penelitian yang dilakukan untuk mengurangi tingkat konsumsi batubara yaitu dengan cara meningkatkan efisiensi dari boiler. Salah satu jenis boiler yang banyak digunakan ialah tangentially fired karena mempunyai kelebihan yaitu pembakaran yang lebih baik dan dapat digunakan untuk jenis batubara yang lebih luas (Y.C. Liu dkk, 2016). Meskipun tangentially fired boiler mempunyai pembakaran yang lebih baik, namun masih terdapat beberapa masalah seperti karbon yang tidak terbakar pada ash, panas yang tidak seimbang dan terdapat deviasi temperatur pada super-heater dan reheater, simulasi numerik dapat secara sukses digunakan untuk mengkaji pembakaran batubara dan dapat mengamati perilaku emisi gas buang dari boiler dengan skala yang besar (Ho Young Park dkk, 2012).

Dalam produksi batubara, Indonesia merupakan salah satu negara produsen batubara dengan mayoritas kualitas batubara yang dihasilkan adalah batubara kalori sedang, padahal masih banyak pembangkit lama yang masih menggunakan batubara kalori rendah. Pada kondisi tertentu pasokan batubara kalori rendah tidak dapat memenuhi kebutuhan pembangkit, sehingga batubara dengan kalori rendah akan dicampur dengan batubara kualitas sedang yang lebih banyak tersedia di unit pembangkit lain (KESDM 2016). Pada sebuah studi simulasi numerik menunjukkan bahwa pada tangentially fired boiler dengan komposisi batubara $70 \%$ batubara kalori rendah dengan $30 \%$ batubara kalori sedang menunjukkan bahwa terjadi penumpukan temperatur yang cukup tinggi dibagian bawah boiler (Sa'adiyah dkk, 2017).

Untuk mengurangi terjadinya deviasi temperatur gas pada boiler dapat dilakukan dengan merubah sudut yaw dari over-fire air, hal ini ditunjukkan dengan hasil simulasi numerik yang menunjukkan bahwa dengan merubah sudut yaw dari Secondary Over-Fire Air (SOFA) merupakan cara yang cukup efektif untuk mengurangi deviasi temperatur gas. Simulasi numerik menunjukkan bahwa dengan merubah sudut dari SOFA dan Closed Couple Over-Fire Air (CCOFA) dapat mempengaruhi temperatur gas dan aliran di daerah sekitar superheater dan reheater (Ho Young Park dkk, 2015). Deviasi kecepatan gas buang secara horizontal berkurang dengan merubah sudut yaw dari SOFA ke arah negatif, dengan Concentric Firing Secondary (CFS) air pada sudut $22^{\circ}$ (Y.C. Liu dkk, 2016). Untuk mengurangi terjadinya deviasi temperatur maka perlu dilakukan optimasi aliran udara dengan arah yang berlawanan dengan arah dari secondary air (Ho Young Park dkk, 2012). Sehingga berdasarkan penelitian tersebut perlu dilakukan penelitian pengaruh sudut yaw burner yang diperkirakan akan dapat mengatasi deviasi temperatur pada bagian bawah boiler yang dapat menentukan kualitas pembakaran batubara didalam boiler yang dapat berpengaruh kepada emisi gas buang yang dihasilkan, dan juga dapat mengatasi kondisi mendatang jika Indonesia kekurangan batubara kalori rendah. Maka dari itu dilakukan studi simulasi numerik karakteristik pembakaran pada tangentially fired boiler dengan variasi sudut yaw.

\section{Metodologi Penelitian}

Metode yang digunakan yaitu simulasi numerik dengan menggunakan Computational Fluid Dynamic (CFD) yang meliputi tiga tahap utama yaitu preprocessing, solving, dan postprocessing.

\subsection{Konsep CFD}

Computational Fluid Dynamics (CFD) merupakan ilmu yang memprediksi aliran fluida, perpindahan panas, perpindahan massa, dan fenomena yang berhubungan dengan pemecahan menggunakan persamaan matematik dimana pengendaliannya menggunakan proses numerik. Persamaan pengendali (Governing equation) dalam dinamika fluida newtonian dikenal sebagai persamaan Navier Stokes. Dalam mereduksi bentuk persamaan Navier Stokes, menjadi penelitian yang masih aktif dikembangkan, terutama pada problematika turbulensi dari persamaan Reynold Averaged Navier Stokes (RANS).

Sejarah penemuan CFD berawal pada tahun 60-an dan mulai dikenal pada tahun 70-an, awal pemakaian konsep CFD hanya terbatas pada aliran fluida dan reaksi kimia, namun seiring dengan berkembangnya industri di tahun 90-an membuat CFD semakin dibutuhkan pada berbagai aplikasi lain. Sebagai contoh 


\section{Simulasi Numerik Karakteristik Pembakaran Pada Tangentially Fired Boiler Dengan Variasi Sudut Yaw}

adalah semakin berkembangnya software CAD yang memiliki kompatibilitas tinggi dengan CFD. Baik dalam kelengkapan tool maupun dalam pendukung konsep perhitungan untuk menganalisis gaya yang terjadi pada model analisis. Pemakaian CFD secara umum dapat dipakai untuk memprediksi aliran suatu fluida beserta distribusi suhunya, transfer massa, perubahan fasa pada proses melting, pengembunan dan pendidihan, reaksi kimia oksidasi, gerakan mekanis yaitu piston, fan dan propeller pada kapal, tegangan dan tumpuan pada benda solid.

\subsection{Preprocessing}

Domain pemodelan yang dibuat terdiri dari coal injection dimodelkan sebagai mass flow inlet, velocity inlet dimodelkan untuk SOFA, CCOFA, primary \& secondary air nozzle. Waterwall-tube pada dinding furnace dimodelkan sebagai wall yang memiliki heat flux, sedangkan heat exchanger akan dimodelkan sebagai porous media yang telah dibuat menjadi potongan-potongan volume sesuai dengan pembagian heat exchanger.

Setelah dilakukan domain pemodelan, dilakukan proses meshing. Meshing adalah suatu proses pemecahan domain menjadi bentuk/ volume yang lebih kecil yang dapat memudahkan diskritisasi domain aliran dan dapat menerapkan persamaan pengendali pada domain aliran. Agar memperoleh simulasi yang tepat dan akurat, maka pemilihan meshing dibuat sesuai dengan mengikuti prediksi perubahan pola aliran yang akan terjadi. Nodes/ Noda pada meshing boiler yang berbentuk hexahedral dan polyhedral untuk pemodelan 3 dimensi boiler. Gambar 1 (a) menunjukkan domain pemodelan boiler dan Gambar 1 (b) menunjukkan meshing pada boiler.

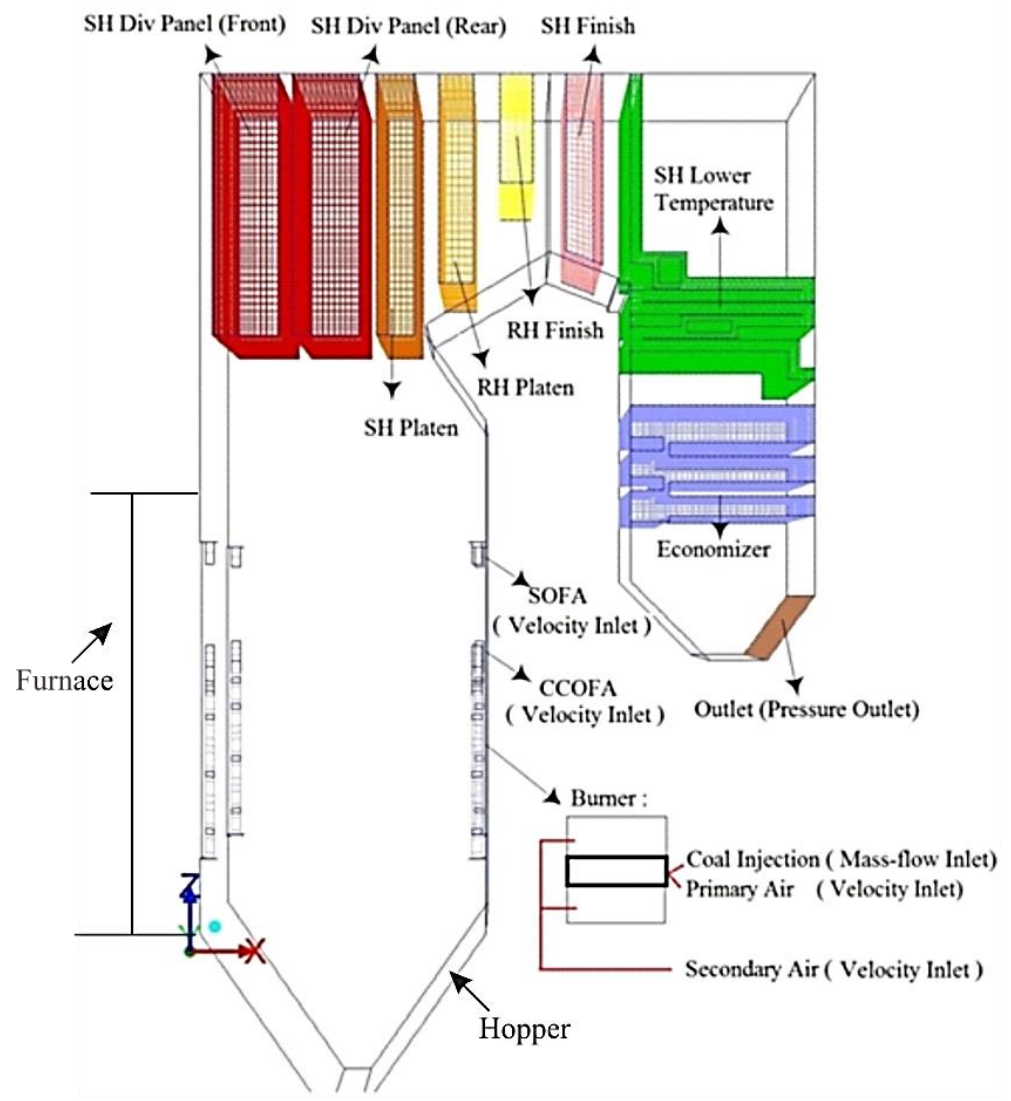

(a) 


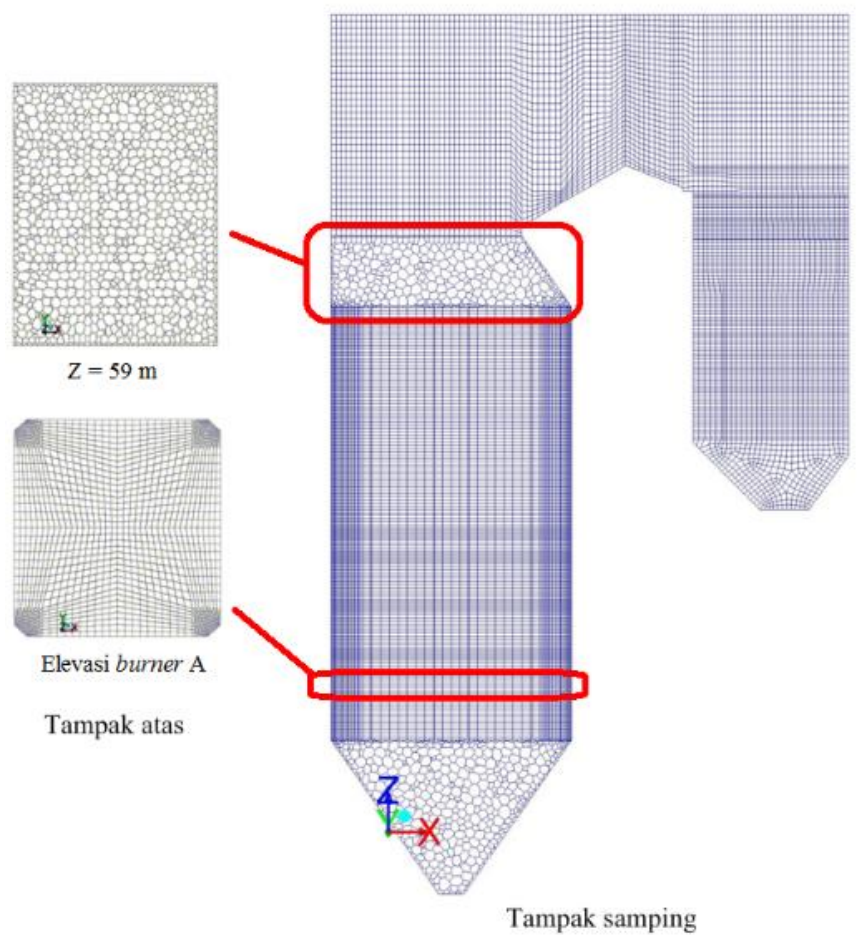

(b)

Gambar 1: (a) Domain Pemodelan Boiler dan (b) Meshing Boiler

\subsection{Processing}

Processing adalah sebuah proses pengaturan simulasi numerik untuk mensimulasikan proses pembakaran yang terjadi pada boiler. Pada pendistribusian fuel atau bahan bakar batubara ke dalam boiler dilakukan penginjeksian batubara melalui burner-burner yang ada pada setiap corner boiler. Terdapat tujuh elevasi burner, yaitu A, B, C, D, E, F, dan G, dimana pada masing-masing elevasi terdiri dari empat burner yang berada pada setiap corner. Pada penelitian ini batubara jenis LRC dengan komposisi $70 \%$ akan diinjeksikan melalui elevasi burner B, D, E, G dan batubara jenis MRC dengan komposisi 30\% akan diinjeksikan melalui elevasi A dan C, sedangkan pada elevasi F pada posisi stand by (di nonaktifkan).

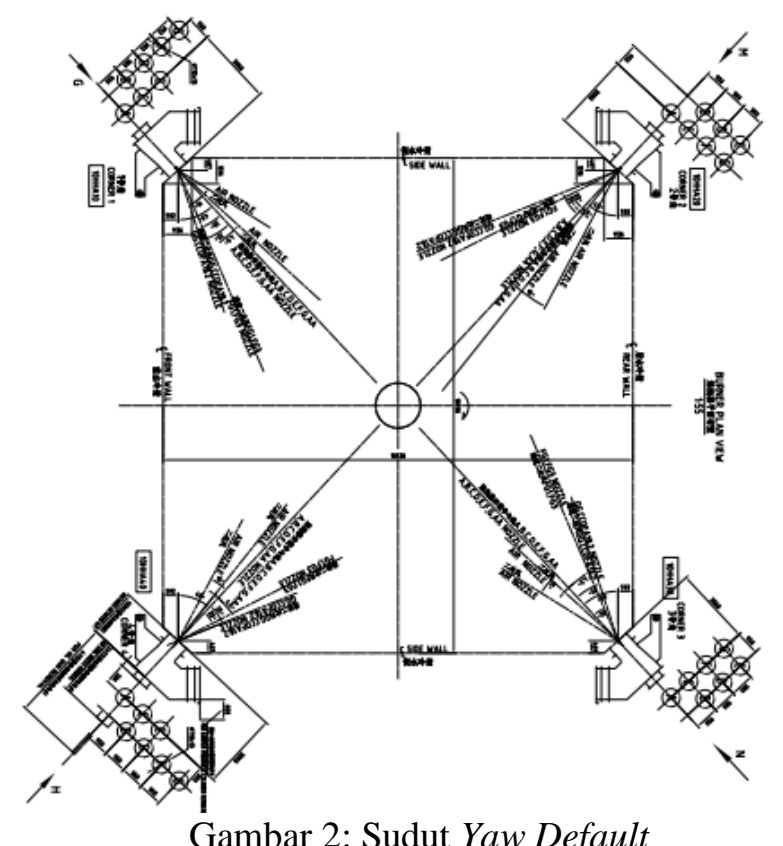

Gambar 2: Sudut Yaw Default 


\section{Sudut Yaw}

Gambar 2 menunjukkan sudut yaw aktual. Batubara diinjeksikan dengan sudut tilt $0^{\circ}$ dan dengan variasi sudut yaw $+5^{\circ}, 0^{\circ},-5^{\circ},-10^{\circ}$, dan $-15^{\circ}$. Sedangkan untuk CCOFA, SOFA dan secondary air masingmasing memiliki pengaturan sudut yaw sesuai dengan data default menurut data manual book Original Equipment Manufacturing (OEM) pada boiler tersebut.

Tabel 1: Model yang Digunakan

\begin{tabular}{|c|c|c|}
\hline Model & Keterangan & Dasar \\
\hline Radiation & Off & Tidak diperlukan \\
\hline Energy equation & On & $\begin{array}{c}\text { Mencakup perpindahan panas radiasi dan } \\
\text { konveksi }\end{array}$ \\
\hline Heat Exchanger & Off & $\begin{array}{l}\text { Heat Exchanger dimodelkan sebagai } \\
\text { porous medium pada cell zone condition } \\
\text { dengan penyerapan heat generation }\end{array}$ \\
\hline Multiphase & Off & $\begin{array}{c}\text { Penelitian dilakukan pada flue gas yang } \\
\text { terjadi akibat pembakaran }\end{array}$ \\
\hline Viscous (model turbulensi) & $k-\varepsilon$ standard & $\begin{array}{c}\text { Dapat menyelesaikan permasalahan } \\
\text { buoyancy, heating, combustion, dan } \\
\text { compressibility. Merujuk pada penelitian } \\
\text { Vuthaluru (2009). }\end{array}$ \\
\hline Species & $\begin{array}{l}\text { Species transport } \\
(\text { NOx }: \text { Thermal NOx })\end{array}$ & $\begin{array}{c}\text { Karena spesies kimia yang diinjeksikan } \\
\text { mempunyai reaksi kimia (pembakaran) } \\
\text { yang telah didefinisikan pada material } \\
\text { yang digunakan. Merujuk pada penelitian } \\
\text { Suhermanto (2012) }\end{array}$ \\
\hline Discrete phase & On & $\begin{array}{c}\text { Mendefinisikan injeksi untuk inlet } \\
\text { batubara }\end{array}$ \\
\hline Solidification & Off & Tidak diperlukan \\
\hline Eulerian Wall Film & Off & Tidak diperlukan \\
\hline Acoustic & Off & Tidak diperlukan \\
\hline
\end{tabular}

Penginjeksian batubara disesuaikan dengan kasus yang akan diteliti dengan meng-inputkan data mass flow rate pada masing-masing elevasi burner. Dimasukkan data velocity inlet dan temperatur pada penginjeksian primary, secondary air nozzle, CCOFA dan SOFA. Ketentuan penginjeksian batubara dan pengaturan sudut yaw secondary air ditunjukkan pada Tabel 2.

Tabel 2: Ketentuan Injeksi Batubara pada Masing- Masing Corner

\begin{tabular}{|c|c|c|}
\hline Parameter & $\begin{array}{r}\text { Per corner coal } \\
\text { injection }\end{array}$ & Dasar pemikiran \\
\hline Material & $\begin{array}{l}\text { Coal mv (MRC) } \\
\text { Lignite (LRC) }\end{array}$ & Kasus PLTU Suralaya unit 8 \\
\hline Injection Type & Group & $\begin{array}{c}\text { Karena pendistribusian batubara saat } \\
\text { memasuki furnace berkelompok } \\
\text { melewati subuah nozzle dengan luasan } \\
\text { tertentu }\end{array}$ \\
\hline Diameter Distribution & Rossin Ramler & $\begin{array}{c}\text { Karena distribusi diameter partikel } \\
\text { batubara tidak memiliki nilai yang tetap }\end{array}$ \\
\hline Particle Type & Combusting & $\begin{array}{l}\text { Reaksi yang terjadi pada partikel yang } \\
\text { diinjeksikan adalah reaksi pembakaran }\end{array}$ \\
\hline Flow Rate $(\mathrm{kg} / \mathrm{s})$ & Terlampir & Data uji coba lapangan \\
\hline $\begin{array}{c}\text { Max diameter }(m) \\
\text { Min diameter }(m) \\
\text { Mean Diameter }(m)\end{array}$ & $\begin{array}{c}0.0002 \\
7 e-05 \\
0.000134\end{array}$ & $\begin{array}{l}\text { Diameter batubara untuk pulverized coal } \\
\text { boiler }\end{array}$ \\
\hline $\begin{array}{l}\text { Spread Diameter }(m) \\
\text { Devolatilizing Species }\end{array}$ & $\begin{array}{c}4,52 \\
m v \text {-coal-vol }(M R C) \\
\text { Lig-vol }(\text { LRC })\end{array}$ & $\begin{array}{c}\text { Asumsi dari tutorial simulasi numerik } \\
\text { Kasus PLTU Suralaya unit } 8\end{array}$ \\
\hline
\end{tabular}


Jenis material yang digunakan adalah material campuran yang terdiri dari LRC dan MRC dengan komposisi batubara yang diinjeksikan pada furnace boiler yaitu 70\% LRC dan 30\% MRC. Data properties pada masing-masing material ditunjukkan pada Tabel 3.

Tabel 3: Properties Material Batubara

\begin{tabular}{|c|c|c|c|}
\hline $\begin{array}{l}\text { Fluent combusting } \\
\text { particle materials }\end{array}$ & Lignite-LRC & $\begin{array}{l}\text { coal-mv- } \\
\text { MRC }\end{array}$ & Dasar Pemikiran \\
\hline $\begin{array}{c}\text { Vaporation Temperatur } \\
(K)\end{array}$ & 423,15 & 423,15 & CFD Data base \\
\hline Volatile Matter (\%) & 33,33 & 33,98 & Data perusahaan \\
\hline Combustion Model & $\begin{array}{l}\text { Multiple surface } \\
\text { reactions }\end{array}$ & $\begin{array}{l}\text { Multiple } \\
\text { surface } \\
\text { reactions }\end{array}$ & $\begin{array}{c}\text { Karena reaksi kimia yang } \\
\text { disimulasikan meliputi reaksi } \\
\text { volumetric dan particle surface }\end{array}$ \\
\hline $\begin{array}{l}\text { React. Heat Fraction } \\
\text { Absorbed by solid (\%) }\end{array}$ & 30 & 30 & \\
\hline $\begin{array}{c}\text { Devolatilization Model } \\
(1 / s)\end{array}$ & 20 & 50 & CFD Data base \\
\hline Density $\left(\mathrm{kg} / \mathrm{m}^{3}\right)$ & 1350 & 1400 & CFD Data base \\
\hline$C p(j / k g K)$ & 1399 & 1500 & CFD Data base \\
\hline $\begin{array}{c}\text { Binary Difusivity }\left(\mathrm{m}^{2} / \mathrm{s}\right) \\
\text { Swelling Coefficient }\end{array}$ & $\begin{array}{c}0,0004 \\
2\end{array}$ & $\begin{array}{c}0,0005 \\
2\end{array}$ & CFD Data base \\
\hline Combustible Fraction (\%) & 29,11 & 36,11 & Data perusahaan \\
\hline
\end{tabular}

Kondisi pengoperasian pada daerah boiler beroperasi adalah dengan memperkirakan tekanan pada daerah boiler beroperasi yaitu $1 \mathrm{~atm}$ atau $101325 \mathrm{~Pa}$. Boundary conditions adalah suatu batasan nilai dan kondisi yang diberikan pada domain aliran agar hasil simulasi sesuai dengan fenomena fisik yang sebenarnya terjadi. Tabel 4 menunjukkan boundary condition untuk nozzle air aktual.

Tabel 4: Boundary Condition untuk Auxiliary Air

\begin{tabular}{|c|c|c|c|}
\hline Auxiliary Air & Angle $\left(^{\circ}\right)$ & Temperatur $\left({ }^{\circ} \mathrm{C}\right)$ & $\operatorname{Kecepatan}(\mathbf{m} / \mathbf{s})$ \\
\hline AA & 0 & 359 & \multirow{8}{*}{ Sesuai data sebenarnya } \\
\hline A & 0 & 66 & \\
\hline $\mathrm{AB}$ & 4.5 & 359 & \\
\hline $\mathrm{B}$ & 0 & 66 & \\
\hline $\mathrm{BC} 1$ & 4.5 & \multirow{2}{*}{359} & \\
\hline $\mathrm{BC} 2$ & 15 & & \\
\hline $\mathrm{C}$ & 0 & 66 & \\
\hline $\mathrm{CD} 1$ & 15 & 359 & \\
\hline $\mathrm{CD} 2$ (LDO) & 4.5 & \multicolumn{2}{|c|}{ Di non-aktifkan (diasumsikan wall) } \\
\hline $\mathrm{CD} 3$ & 15 & \multicolumn{2}{|c|}{359} \\
\hline $\mathrm{D}$ & 0 & \multicolumn{2}{|l|}{66} \\
\hline DE1 & 15 & \multirow{2}{*}{359} & \multirow{3}{*}{ Sesuai data sebenarnya } \\
\hline DE2 & 4.5 & & \\
\hline $\mathrm{E}$ & 0 & 66 & \\
\hline $\mathrm{EF}$ & 4.5 & 359 & \\
\hline $\mathrm{F}$ & 0 & 66 & \\
\hline FG1 & -20 & 359 & \\
\hline FG2 (LDO) & 4.5 & \multicolumn{2}{|c|}{ Di non-aktifkan (diasumsikan wall) } \\
\hline FG3 & -20 & 359 & \multirow{5}{*}{ Sesuai data sebenarnya } \\
\hline $\mathrm{G}$ & 0 & 66 & \\
\hline GG & -25 & & \\
\hline CCOFA $1 \& 2$ & -25 & 359 & \\
\hline SOFA $1 \& 2$ & 0 & & \\
\hline
\end{tabular}


Solusi yang digunakan pada penelitian ini yaitu dengan menggunakan algoritma SIMPLE (Semi-Implicit Method for Pressure-Linked Equations) yang mana least squares cell based untuk gradient, standard untuk pressure, first order upwind untuk turbulent kinetic energy dan turbulent dissipation rate, dan second order upwind untuk momentum, lig-vol, $\mathrm{O}_{2}, \mathrm{CO}_{2}, \mathrm{H}_{2} \mathrm{O}, \mathrm{H}_{2}$ dan $\mathrm{CO}$. Penggunaan solusi tersebut berdasarkan penelitian oleh Chungen, dkk (2002) dan Choi dan Kim (2008).

Kemudian dilakukan tahap initialize. Initialize adalah tebakan awal atau hipotesa awal dari sebelum melakukan perhitungan sehingga dapat memudahkan dalam mencapai konvergen. Tebakan dapat dimulai dari kondisi batas sisi keluar, masuk, semua wilayah dan lainnya. Initialize yang digunakan adalah hybrid initialize. Nilai konvergen ditetapkan sebesar $10^{-3}$ yang berarti proses iterasi dinyatakan konvergen setelah residualnya mencapai nilai dibawah nilai konvergen yang telah ditetapkan. Namun jika tidak tercapai konvergen, maka sebagai proses validasi dilakukan pengambilan data pada iterasi tertentu dimana memiliki nilai parameter yang hampir serupa dengan data aktual.

\subsection{Post Processing}

Post-processing adalah penampilan hasil simulasi yang telah diporeleh berupa data kuantitatif berupa grafik maupun tabel data dan berupa data kualitatif seperti kontur, vektor. Pada penelitian ini analisa dilakukan terhadap distribusi temperatur yang berupa grafik dan kontur, dan distribusi kecepatan yang berupa kontur.

\section{Hasil dan Pembahasan}

Dalam penelitian ini menggunakan metode simulasi untuk mengetahui pengaruh variasi sudut yaw coal burner terhadap karakteristik pembakaran dan emisi gas buang pada tangentially fired boiler. Karakteristik pembakaran pada penelitian ini ditunjukkan dengan sebaran temperatur dan vektor kecepatan.

\subsection{Validasi}

Sebelum melakukan analisa hasil simulasi, data dari hasil simulasi harus terlebih dahulu dilakukan validasi untuk memastikan bahwa hasil yang diperoleh dari simulasi identik atau mendekati dengan data dari hasil pengukuran aktual, sehingga data hasil simulasi dapat digunakan. Validasi dilakukan dengan sudut yaw coal burner $0^{\circ}$, hal ini dikarenakan sudut $0^{\circ}$ merupakan sudut aktual dari coal burner. Proses validasi dilakukan dengan membandingkan data emisi gas buang $\mathrm{CO}_{2}$ dan $\mathrm{O}_{2}$ pada sisi outlet (keluaran) boiler.

Pengambilan data emisi gas buang dilakukan pada jumlah iterasi 8400 karena mempunyai nilai yang paling mendekati dengan data aktual. Data emisi gas buang $\mathrm{O}_{2}$ dan $\mathrm{CO}_{2}$ yang telah diperoleh kemudian dibandingkan dengan data aktual yang ditunjukkan pada Tabel 2 .

Tabel 2: Tabel Perbandingan Antara Data Aktual dengan Simulasi

\begin{tabular}{cccc}
\hline Jenis & Data Aktual (\%) & Data Simulasi (\%) & Error \\
\hline $\mathrm{O}_{2}$ & 5,4 & 5,9 & $9 \%$ \\
$\mathrm{CO}_{2}$ & 14,8 & 15,5 & $4,7 \%$ \\
\hline
\end{tabular}

Tabel 2 menunjukkan bahwa terjadi error yang cukup kecil pada emisi gas buang $\mathrm{CO}_{2}$ yaitu dibawah $5 \%$, sedangkan pada emisi gas buang $\mathrm{O}_{2}$ terjadi perbedaan sebesar $9 \%$, hasil simulasi menunjukkan bahwa data emisi gas buang yang diperoleh pada sisi outlet cukup konsisten mendekati data yang sebenarnya dikarenakan error masih berada dibawah $10 \%$, hal ini merujuk pada penelitian sebelumnya dimana error yang terjadi pada emisi gas buang antara data aktual dan simulasi mempunyai error sebesar 16\% (Ho Young Park dkk, 2012) dan error sebesar 11\% (Tan dkk, 2017). Sehingga simulasi ini dapat digunakan untuk penelitian yang lebih lanjut.

\subsection{Distribusi Temperatur}




\section{Simulasi Numerik Karakteristik Pembakaran Pada Tangentially Fired Boiler Dengan Variasi Sudut Yaw}

Pengamatan distribusi temperatur pada y-center dilakukan untuk mengetahui distribusi temperatur yang terjadi dari furnace sampai keluar dari boiler. Gambar 3 menunjukkan perbandingan hasil simulasi sebaran temperatur y-center antara sudut yaw coal burner $0^{\circ},+5^{\circ},-5^{\circ},-10^{\circ}$, dan $-15^{\circ}$. Warna Jingga sampai merah menunjukkan temperatur pada bagian furnace lebih tinggi dibandingkan dengan ketika memasuki jajaran heat exchanger yang ditandai oleh warna hijau sampai biru dikarenakan terjadi pembakaran pada bagian furnace sehingga terjadi temperatur yang tinggi, sedangkan pada jajaran heat exchanger terjadi penyerapan panas sehingga temperatur menjadi rendah. Temperatur yang terjadi berkisar antara $339,15 \mathrm{~K}-2200 \mathrm{~K}$.
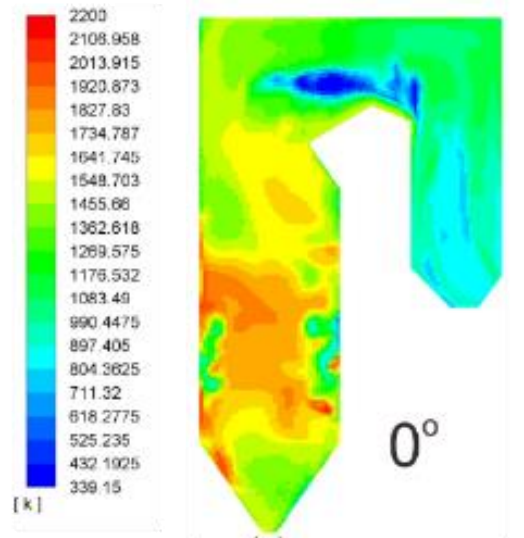

(a)

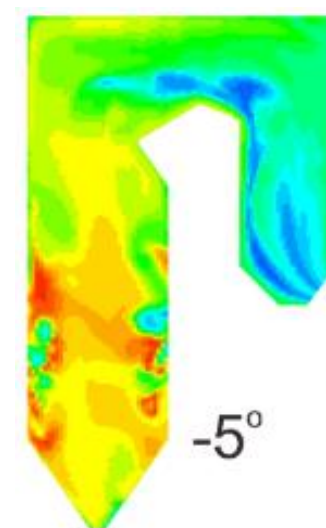

(c)

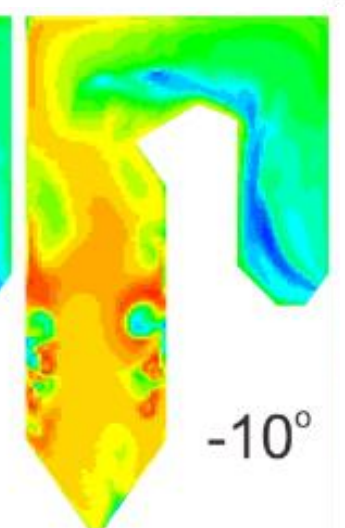

(d)

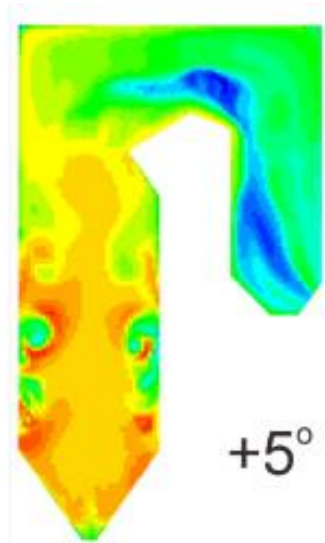

(b)

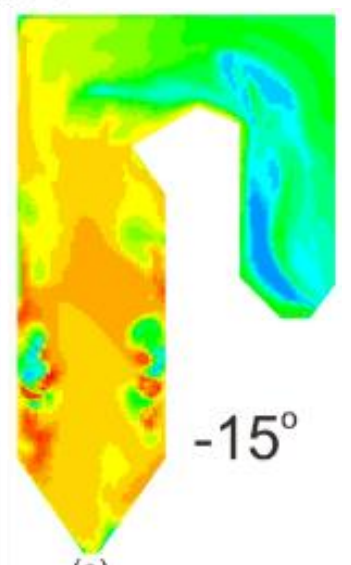

(e)

Gambar 3: Kontur Temperatur Pada Y-center

Temperatur yang tinggi yang terjadi pada bagian outlet furnace dihasilkan oleh karbon yang tidak terbakar sempurna pada furnace, sehingga terjadi peningkatan panas gas buang dan dapat menimbulkan potensi panas berlebih (overheat) pada superheater (Chen dkk, 2017). Gambar 3 (a) sudut yaw coal burner $0^{\circ}$ menunjukkan sebaran temperatur yang tinggi pada bagian furnace dan memiliki temperatur yang paling rendah pada saat memasuki jajaran heat exchanger di antara variasi sudut yang lain, namun pada sudut $0^{\circ}$ masih memiliki beberapa temperatur yang tidak merata atau tidak seimbang pada bagian furnace yang ditandai oleh adanya bagian yang berwarna merah yang ada pada furnace dimana terjadi penumpukan temperatur pada sebelah kiri dinding furnace. Bola api yang terbentuk pada sudut $0^{\circ}$ berada pada bagian tengah furnace, terjadinya temperatur yang tinggi pada bagian pusat furnace dikarenakan burner tepat mengarah ketengah sehingga bola api yang dihasilkan lebih memusat. Gambar 3 (b) sudut yaw coal burner $+5^{\circ}$ menunjukkan sebaran temperatur yang tinggi dari bagian bawah furnace sampai dengan sesaat sebelum memasuki jajaran heat exchanger dengan temperatur berkisar antara 1700-1800 K. Bola api yang terjadi cenderung mengarah pada bagian bawah boiler. Temperatur yang ada pada sudut $+5^{\circ}$ masih memiliki beberapa temperatur yang tidak merata atau tidak seimbang pada bagian furnace yang ditandai oleh adanya bagian yang berwarna merah yang ada pada furnace. Secara keseluruhan sebaran temperatur yang terjadi pada furnace cukup merata, namun memiliki temperatur yang cukup tinggi pada saat keluar dari furnace. Terbentuknya temperatur yang tinggi pada bagian 


\section{Simulasi Numerik Karakteristik Pembakaran Pada Tangentially Fired Boiler Dengan Variasi Sudut Yaw}

bawah furnace dikarenakan pada sudut yaw coal burner $+5^{\circ}$ memiliki arah yang mendekati arah dari CCOFA sehingga saling menumpuk satu dengan lainnya. Gambar 3 (c) sudut yaw coal burner $-5^{\circ}$ menunjukkan sebaran temperatur yang paling rendah, dimana ditunjukkan oleh masih banyaknya kontur berwarna kuning pada bagian furnace. Bola api cenderung mengarah ke bagian atas furnace. Distribusi temperatur pada sudut $-5^{\circ}$ masih memiliki beberapa temperatur yang tidak merata atau tidak seimbang pada bagian furnace yang ditandai oleh adanya bagian yang berwarna merah yang ada pada furnace. Sebaran temperatur pada saat keluar dari furnace bernilai paling rendah dibandingkan dengan variasi sudut yang lain yang ditandai dengan kontur kuning yang lebih sedikit pada saat keluar dari furnace. Temperatur tinggi yang terbentuk pada dinding furnace sebelah kiri pada bagian SOFA dikarenakan sudut SOFA yang mengarah ke pusat furnace sehingga tidak dapat berperan maksimal sesuai fungsinya untuk menurunkan temperatur sebelum mencapai heat exchanger. Gambar 3 (d) sudut yaw coal burner $-10^{\circ}$ menunjukkan sebaran temperatur yang paling tinggi dibandingkan semua variasi sudut yang ditunjukkan dengan kontur berwarna jingga yang menyebar dari furnace sampai dengan jajaran superheater. Temperatur yang tidak merata atau tidak seimbang juga masih terjadi pada bagian furnace ditandai oleh cukup banyak bagian yang berwarna merah yang ada pada furnace. Bola api cenderung mengarah kebagian atas furnace yang terjadi dikarenakan semakin melebarnya sudut burner sehingga membuat bola api yang lebih meluas sehingga susah untuk diturunkan temperaturnya setelah keluar dari furnace. Gambar 3 (e) sudut yaw coal burner $-15^{\circ}$ menunjukkan sebaran temperatur yang menyerupai dengan sudut $-10^{\circ}$, yang memiliki sebaran temperatur tinggi yang menyebar dari furnace sampai dengan bagian atas furnace. Temperatur yang tinggi juga masih terdapat ketika masuk ke jajaran heat exchanger. Temperatur yang tidak merata atau tidak seimbang juga masih terjadi pada bagian furnace yang ditandai oleh adanya bagian yang berwarna merah yang ada pada furnace. Bola api yang terbentuk cenderung mengarah kebagian atas furnace yang terjadi dikarenakan semakin melebarnya sudut burner sehingga membuat bola api yang lebih meluas sehingga susah untuk diturunkan temperaturnya setelah keluar dari furnace. Diperoleh sebaran temperatur yang paling baik yaitu sebaran temperatur pada boiler dengan sudut yaw coal burner $-5^{\circ}$ dikarenakan pada sudut $-5^{\circ}$ sebaran temperatur yang terjadi setelah keluar dari furnace mempunyai temperatur yang paling rendah sehingga dapat meminimalisir resiko terjadinya overheat pada superheater.

Pengamatan distribusi temperatur pada setiap elevasi bertujuan untuk mengetahui pengaruh perubahan sudut yaw terhadap distribusi temperatur yang dihasilkan

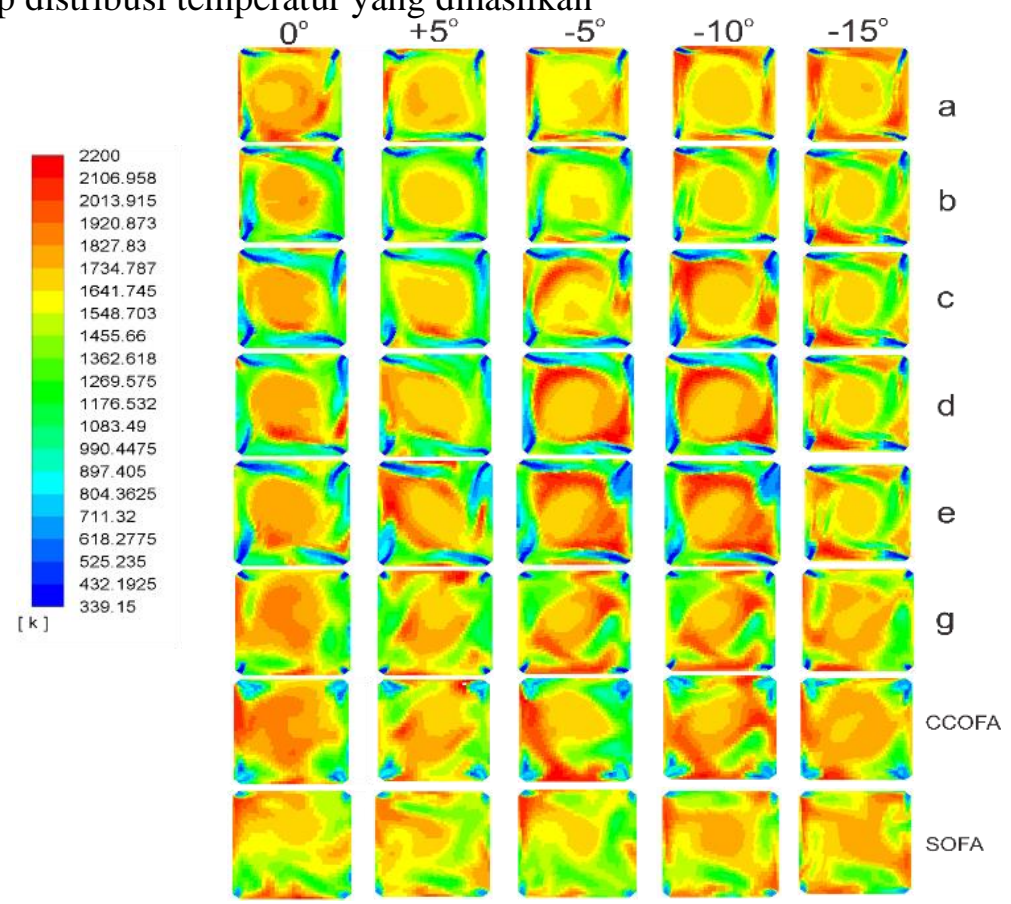

Gambar 4: Kontur Temperatur Pada Setiap Elevasi Furnace

Gambar 4 menunjukkan pada elevasi coal burner A. Pembentukan bola api pada sudut $0^{\circ}$ dapat terlihat terjadi pembentukan bola api namun masih terdapat temperatur yang tinggi pada dinding-dinding 


\section{Simulasi Numerik Karakteristik Pembakaran Pada Tangentially Fired Boiler Dengan Variasi Sudut Yaw}

furnace, hal yang sama terjadi pada variasi sudut lainnya yang menunjukkan temperatur yang lebih tinggi pada sisi dinding furnace yang dikarenakan bantuan dari nozzle udara sekunder AA mengarah kebagian pusat. Pembentukan bola api pada elevasi coal burner B pada semua variasi sudut dapat terlihat semua membentuk bola api yang dikarenakan telah mendapat bantuan dari udara sekunder yaitu nozzle $\mathrm{AB}$ yang membantu mengarahkan bola api kepusat dengan sudut yaw $4,5^{\circ}$, temperatur yang cukup tinggi pada bagian-bagian dinding sudut yaw coal burner $-10^{\circ}$ dan $-15^{\circ}$ dikarenakan sudut yaw coal burner yang terlalu melebar sehingga akan melebarkan lingkaran bola api yang berakibat akan menyebar ke dinding-dinding furnace. Pembentukan bola api pada elevasi coal burner $\mathrm{C}$ sampai dengan $\mathrm{E}$ pada semua variasi sudut menunjukkan pembentukan lingkaran bola api yang lebih konsisten dan identik. Lingkaran bola api pada sudut $-5^{\circ}$ dan $-10^{\circ}$ memiliki temperatur yang lebih tinggi ditandai dengan kontur berwarna merah yang mengelilingi bola api yang menandakan terjadi pembakaran secara tangensial yang baik dikarenakan bola api berada pada tengah-tengah furnace, dan mempunyai temperatur yang lebih tinggi pada daerah pembakaran. Bola api yang terbentuk pada elevasi coal G, pada semua variasi sudut masih terlihat adanya lingkaran bola api, namun bentuk bola api menjadi tidak baik dikarenakan tidak dinyalakannya coal burner F dan udara sekunder FG yang mana sesuai dengan kondisi aktual sehingga menyebabkan temperatur yang lebih tinggi terdapat pada bagian dinding-dinding furnace, sedangkan pada bagian elevasi CCOFA, pada semua variasi sudut, masih terjadi pembentukan bola api, namun pada sudut $-5^{\circ}$ dan $-10^{\circ}$ memiliki temperatur yang lebih tinggi dibandingkan dengan variasi sudut lainnya dan juga memiliki temperatur yang lebih tinggi pada sebagian dinding furnace. Lingkaran bola api yang terbentuk pada elevasi SOFA pada sudut $0^{\circ},+5^{\circ}$, dan $-5^{\circ}$ terlihat mulai mengecil dan menunjukkan penurunan temperatur, dimana rata-rata temperatur paling rendah berada pada sudut $-5^{\circ}$, yang menandakan SOFA berfungsi sebagaimana mestinya untuk menurunkan temperatur sebelum keluar dari furnace, sedangkan pada sudut $-10^{\circ}$ dan $15^{\circ}$ masih terdapat lingkaran bola api yang cukup besar pada SOFA yang menandakan SOFA tidak berfungsi sesuai dengan tugasnya yaitu SOFA tidak mampu menurunkan temperatur sebelum flue gas keluar dari furnace. Berdasarkan kontur temperatur pada setiap elevasi diperoleh sebaran temperatur dan lingkaran tangensial terbaik pada sudut yaw coal burner $-5^{\circ}$, dikarenakan pada sudut $-5^{\circ}$ terjadi ligkaran tangensial yang lebih baik dibandingkan dengan variasi sudut lainnya, dan juga memiliki temperatur yang lebih tinggi pada daerah pembakaran yang merujuk pada penelitian sebelumnya yang dilakukan oleh Chen (Chen dkk, 2017). Berdasarkan kontur temperatur juga diperoleh bahwa pada sudut yaw coal burner $-5^{\circ}$ memiliki rata-rata kontur temperatur yang paling rendah pada bagian elevasi SOFA, yang mana merujuk pada penelitian sebelumnya yang menyatakan jika terjadi temperatur yang tinggi pada bagian sesaat sebelum dan sesudah keluar dari furnace diakibatkan oleh karbon yang tidak terbakar, dan juga dapat meningkatkan potensi terjadinya overheat pada superheater (Chen dkk, 2017). Tugas SOFA adalah menurunkan deviasi temperatur yang terjadi pada saat flue gas akan memasuki daerah superheater, yang mana dapat merusak tube pada superheater akibat terjadi overheat (Ho Young Park dkk, 2012), untuk mendukung analisa data kualitatif dari kontur distribusi temperatur, dilakukan analisa data kuantitatif dari rata-rata temperatur di setiap elevasi. 


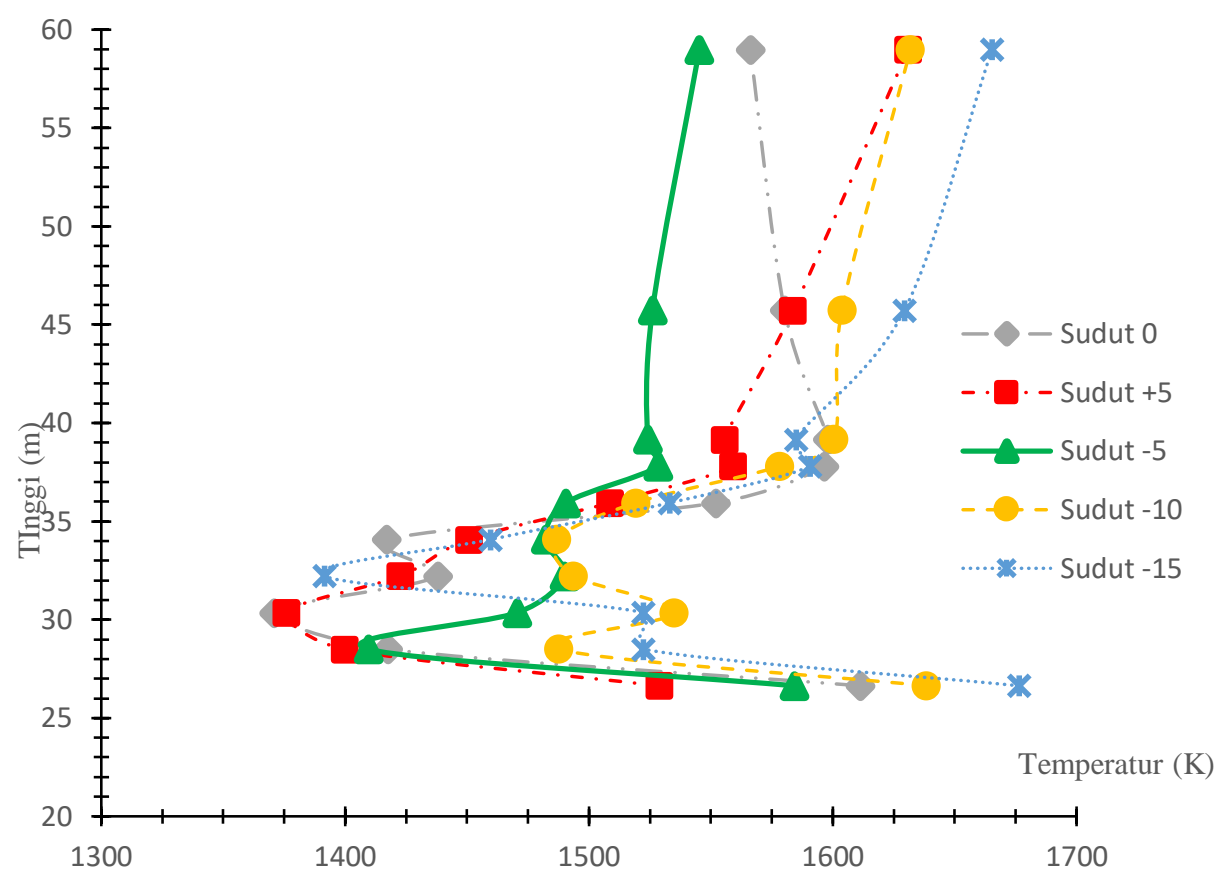

Gambar 5: Grafik Rata-Rata Temperatur Pada Setiap Elevasi

Gambar 5 menunjukkan grafik rata-rata temperatur setiap variasi sudut terhadap setiap elevasi, pada sudut yaw coal burner $0^{\circ}$, temperatur tertinggi berada pada elevasi $26 \mathrm{~m}$, begitu pula dengan variasi sudut $-15^{\circ},-10^{\circ}$, dan $-5^{\circ}$, temperatur kemudian mengalami penurunan sampai ketinggian $30 \mathrm{~m}$, penurunan paling drastis terjadi pada sudut yaw $-15^{\circ}$ dan $0^{\circ}$, kemudian temperatur mengalami kenaikan pada elevasi $35 \mathrm{~m}$ sampai dengan elevasi $38 \mathrm{~m}$, pada sudut yaw $0^{\circ}$ menunjukkan kenaikan yang paling sedikit atau dapat dikatakan temperatur yang terjadi lebih rata. Temperatur yang terjadi dari elevasi 38 $\mathrm{m}$ sampai dengan $60 \mathrm{~m}$ pada sudut $0^{\circ}$ temperatur cenderung mengalami penurunan, sedangkan pada sudut $+5^{\circ},-15^{\circ}$, dan $-10^{\circ}$ cenderung mengalami kenaikan temperatur, sedangkan pada sudut $-5^{\circ}$ dapat terlihat secara jelas mempunyai temperatur yang mendekati konstan atau sama. Temperatur yang terjadi pada sudut yaw coal burner $-15^{\circ}$ cenderung fluktuatif dikarenakan pengaruh dari udara sekunder yang ada pada setiap himpitan burner. Semakin melebar sudut yaw coal burner terlihat bahwa temperatur yang terjadi pada setiap elevasi lebih fluktuatif yang menandakan tidak meratanya temperatur. Sudut $10^{\circ}$ sekilas terlihat memiliki temperatur yang lebih konstan dibandingkan dengan sudut yang lain, namun data yang ditunjukkan pada Tabel 2 Lampiran B sudut $-5^{\circ}$ memiliki perbedaan rata-rata temperatur yang paling kecil, dan temperatur terendah pada bagian SOFA ke atas, rata-rata temperatur pada sudut $-10^{\circ}$ masih lebih tinggi dibandingkan dengan sudut $-5^{\circ}$. Temperatur pada sudut yaw coal burner $-5^{\circ}$ menunjukkan perubahan rata-rata temperatur terkecil pada setiap elevasi yang berarti perubahan temperatur rata-rata yang terjadi pada setiap elevasi mempunyai temperatur yang cukup merata. Temperatur pada sudut yaw coal burner $-5^{\circ}$ juga menunjukkan temperatur yang paling kecil pada saat ketinggian $59 \mathrm{~m}$ yang menandakan bahwa pada sudut $-5^{\circ}$ memiliki resiko yang paling kecil terhadap terjadinya overheat pada superheater.

Pengamatan distribusi kecepatan bertujuan untuk mengetahui pengaruh dari perubahan sudut yaw coal burner $0^{\circ},+5^{\circ},-5^{\circ},-10^{\circ}$, dan $-15^{\circ}$. Pembentukan bola api pada tangentially fired boiler lebih mudah diamati dengan melakukan pengamatan dari vektor-vektor kecepatan yang terbentuk pada setiap elevasi furnace. Distribusi vektor kecepatan pada setiap elevasi ditunjukkan pada Gambar 6. 

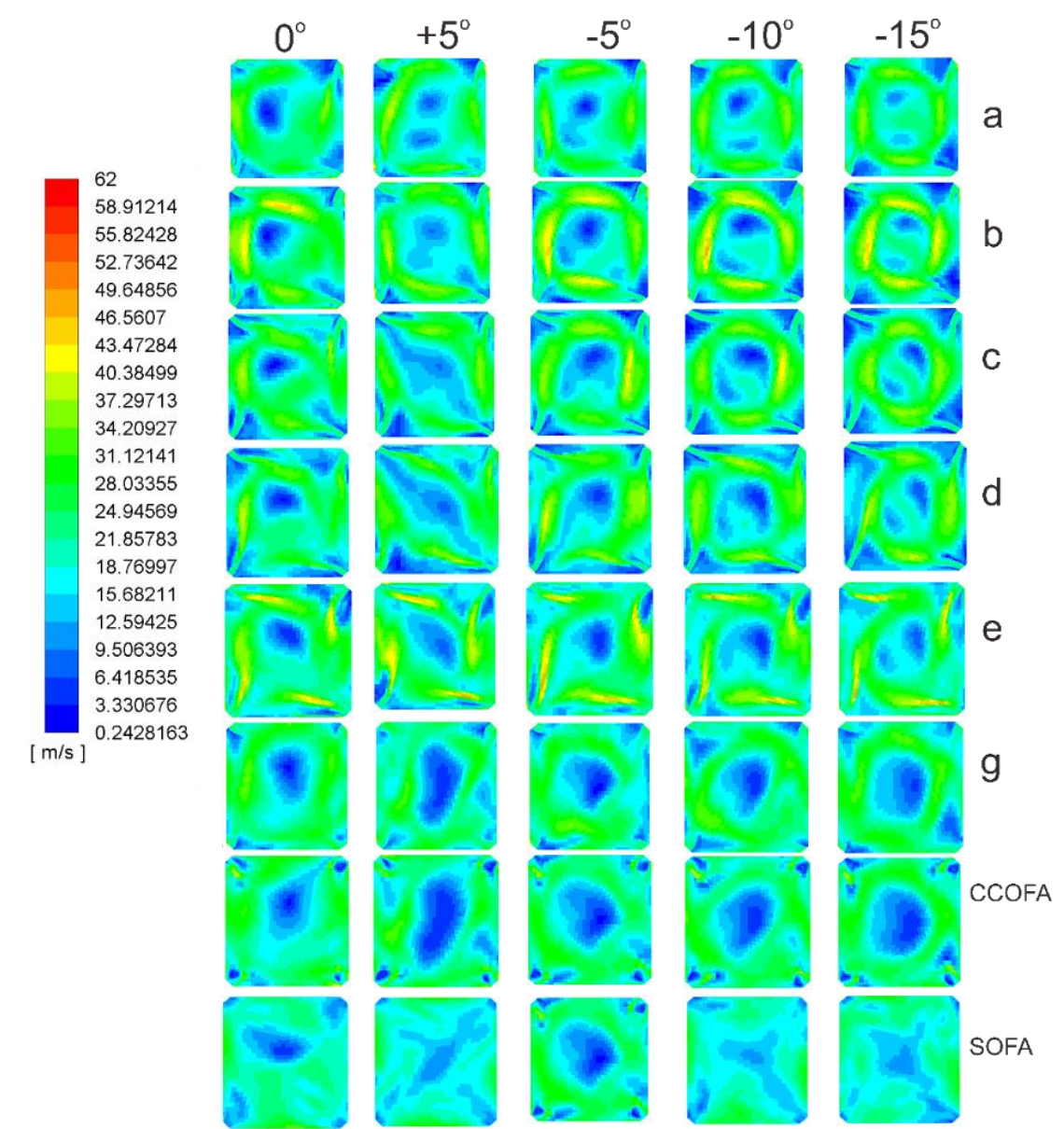

Gambar 6: Distribusi Kecepatan Pada Setiap Elevasi Furnace

Gambar 6 menunjukkan pada setiap variasi sudut memiliki distribusi kecepatan yang mengarah ke pusat. Sirkulasi tangensial yang baik akan meningkatkan distribusi pengapian yang baik (Al-Abbas, 2012). Distribusi kecepatan yang paling seragam pada bagian furnace yang dapat mengurangi terjadinya deviasi temperatur (Chen dkk, 2017). Sudut $0^{\circ}$ memiliki distribusi kecepatan yang konsisten pada elevasi A sampai dengan CCOFA yang membentuk lingkaran tangensial yang baik, namun pada saat elevasi SOFA distribusi kecepatan cenderung tidak beraturan, pada sudut $+5^{\circ}$ belum terdapat lingkaran tangensial yang baik pada elevasi A sampai dengan D, ketika memasuki elevasi E sampai dengan CCOFA distribusi kecepatan yang terjadi semakin melebar, lalu pada elevasi SOFA terjadi penurunan distribusi kecepatan dan tidak terbentuk lingkaran tangensial, pada sudut $-5^{\circ}$ dari elevasi A sampai dengan SOFA menunjukkan distribusi kecepatan yang sama, yaitu mengarah kepusat. Sudut $-10^{\circ}$ dan $15^{\circ}$ memiliki distribusi kecepatan yang cenderung identik antara satu sama lain, namun pada elevasi SOFA tidak terbentuk distribusi kecepatan yang mempunyai bentuk lingkaran tangensial, pada semua variasi sudut, distribusi kecepatan yang terbentuk cenderung sama, namun terdapat sedikit perbedaan pada konsistensi pembentukan kecepatan dengan bentuk lingkaran tangensial. Perbedaan distribusi kecepatan pada setiap variasi sudut yaw coal burner dikarenakan pengaruh nozzle udara sekunder yang berada di setiap himpitan burner. Distribusi kecepatan yang terjadi pada furnace dapat berpengaruh terhadap pambentukan bola api. Secara keseluruhan, diperoleh distribusi kecepatan terbaik pada sudut yaw coal burner $-5^{\circ}$ dikarenakan mempunyai distribusi kecepatan tangensial yang baik, yang mempunyai distribusi mengarah pada bagian pusat zona furnace dibandingkan dengan sudut yang lain dan memiliki distribusi kecepatan yang seragam pada furnace.

\section{Kesimpulan}

Perubahan sudut yaw coal burner dapat mempengaruhi distribusi temperatur yang terjadi pada furnace, semakin lebar sudut yaw coal burner semakin tinggi pula deviasi temperatur yang terjadi pada bagian atas furnace. Sudut yaw coal burner yang memiliki distribusi temperatur terbaik yaitu pada sudut $-5^{\circ}$ 


\section{Simulasi Numerik Karakteristik Pembakaran Pada Tangentially Fired Boiler Dengan Variasi Sudut Yaw}

karena memiliki pembentukan lingkaran bola api terbaik dengan temperatur yang tinggi pada bagian furnace dan temperatur terendah di bagian upper furnace.

\section{Daftar Pustaka}

Al-Abbas, Audai Hussein dkk. (2012), 'CFD modelling of air-fired and oxy-fuel combustion in a large-scale furnace at Loy Yang A brown coal power station'. Fuel 102 (2012), 646-665.

Al-Abbas, Audai Hussein dkk. (2012), 'Numerical simulation of brown coal combustion in a 500 MW tangentially-fired furnace under different operating conditions', Fuel xxx (2012), xxx-xxx.

BUMN, (2017), Produksi Batubara Indonesia. [online] tersedia di http:// bumn.go.id/bukitasam/berita/2-Batubaradi-Indonesia-Produksi-Ekspor-Batubara - Indonesia- [diakses pada tanggal 22 juli 2018].

Chen, Shinan., dkk., (2017), 'Numerical investigations on different tangential arrangements of burners for a 600 MW utility boiler', Energy 122 (2017), 287-300.

Choi, Choeng Ryul., dan Chang Nyung Kim., (2008), 'Numerical investigation on the flow, combustion and NOx emission characteristics in a 500MWe tangentially fired pulverized-coal boiler;'. Fuel 88 (2009), 17201731.

Chungen, Yin., Rosendahl, Lasse., Condra, Thomas J., (2002), 'Further study of the gas temperature deviation in large-scale tangentially coal-fired boilers'. Fuel 82 (2003), 1127-1137.

ESDM, (2018), Cadangan Batubara Indonesia. [online] tersedia di : https://www.esdm.go.id/id/mediacenter/arsip-berita/cadangan-batubara-indonesia-sebesar-26-miliar-ton [diakses pada tanggal 22 juli 2018].

KESDM, (2016), Laporan Kinerja Direktorat Jenderal Mineral dan Batubara, KESDM Jakarta.

Liu, Y.C., dkk., (2017), 'Experimental and numerical studies on the gas velocity deviation in a $600 \mathrm{MWe}$ tangentially fired boiler'. Applied Thermal Engineering 110 (2017), 553-563.

Park, Ho Young., dkk., (2012), 'Numerical and experimental investigations on the gas temperature deviation in a large scale, advanced low NOx, tangentially fired pulverized coal boiler’. Fuel 104 (2013), 641-646.

Park, Ho Young., dkk., (2016), 'Reduction of main steam temperature deviation in a tangentially coal-fired, two pass boiler'. Fuel 166 (2016), 509-516.

Sa'adiyah, D.S., dkk., (2017), 'Studi Numerik Karakteristik Aliran, Pembakaran dan Emisi Gas Buang pada Tangentially Fired Boiler 625 MWe dengan Komposisi Batubara 70\% LRC dan 30\% MRC pada Kondisi Pengoperasian yang Berbeda’, Institut Teknologi Sepuluh Nopember, Surabaya. 